\title{
A VÉDJEGYEK SZEREPE, ÉS FOGYASZTÓI MEGÍTÉLÉSE
}

\author{
Totth Gedeon - Kovács Ildikó - Mezőné Oravecz Titanilla Éva - Mucha László
}

\begin{abstract}
Absztrakt: A jóléti társadalmakban, így hazánkban is, korábban soha nem látott termékmennyiség, és termék választék próbálja kielégíteni a már létező, vagy még meg sem született fogyasztói igényeket. Azonban a kínálat bövülésével a fogyasztói döntéshozatal megnehezedik. A termékválaszték, valamint a csomagolásokon feltüntetett adatok olyan információ-dömpinggel látják el a fogyasztót, aminek feldolgozása nagyon nehezen lehetséges. A vásárlás során a fogyasztók számtalan döntési, funkcionális, pszichológiai, társadalmi, és egyéb kockázattal szembesülnek, melyek csökkentésére különböző stratégiákat alkalmaznak. Ilyen döntési kockázatcsökkentő eszköz a védjegyes termékek választása. A védjegyek szerepe az élelmiszerek esetében - ahol sok tömegtermék fellelhető - kiemelten fontos. Jelen tanulmányunk a hazai élelmiszerekre irányuló fogyasztói magatartás elemzésével foglalkozik. Kutatási célunk az általánosan elfogadott nemzetközi skálák (CETSCALE, 1-7 Likert-skála) alkalmazásával a hazai fogyasztói etnocentrizmus vizsgálata, valamint a védjegyek - azon belül is elsősorban a Magyar Termék, Hazai Termék, Hazai Feldolgozású Termék tanúsító védjegyek - ismertségének, és a hozzájuk kapcsolódó vásárlói attitüdnek a megismerése. Az 551 fő megkérdezésével elvégzett kutatásunk eredményei segítséget nyújthatnak a magyar élelmiszeripari vállalkozások számára a fogyasztói preferenciák megismerésében, a megfelelő védjegy-stratégia kialakításában, és ezáltal versenyképességük növelésében.
\end{abstract}

Abstract: In welfare societies, including Hungary, the amount of product and product range that we have never seen before is trying to satisfy existing or not yet born consumer needs. However, consumer decision-making becomes more difficult with the expansion of supply. The product range and the information on the packaging provide information dumping to customers, which is very difficult to process. Consumers face numerous decision-making, functional, psychological, social, and other risks during shopping, and various strategies are being used to reduce them. Such a decisionmaking risk reduction tool is choosing branded products. The role of trademarks in food - where many mass products are found - is very important. This article aims to present an analysis of consumer behavior towards domestic food. By using the internationally accepted international scales (CETSCALE, 1-7 Likert-scale) our research goal is to examine domestic consumer ethnocentrism, and to analyze the recognition, and customer attitudes of trademarks, especially the Hungarian Product, Home Product, and Domestic Process Product. The results of our research conducted by 551 people can help Hungarian food companies to understand consumer preferences, develop a proper trademark strategy that increases their competitiveness.

Kulcsszavak: tanúsító védjegyek, etnocentrizmus, fogyasztói magatartás

Keywords: trademarks, ethnocentrism, consumer behavior

\section{Bevezetés}

Napjainkban hatalmas termékmennyiség, és termék választék áll a vásárlók rendelkezésére. Betancourt - Gautschi (1990) szerint a nagy választék számos elönnyel jár a fogyasztók számára, hiszen viszonylag kis keresési költséggel találhatják meg a megfelelő termékeket. A sok termék emellett csökkentheti a bizonytalanságot és megfelelő információval látja el a vásárlót.

A nagy választék lehetővé teszi, hogy a termékeket az egész háztartás számára egy helyen vegyék meg, amellett, hogy a hedonisztikus és élvezeti értékét növelik a vásárlásnak (Babin és mtsai, 1994) és a nem vásárlási célú tevékenységeket, mint az információszerzés, új termékek megismerése is kielégíthetik. Malhotra (1982) 
szerint a vásárlási döntésre az információs túlkínálat a kutatások szerint negatív hatással van, és ilyenkor a vásárlók rosszabb döntést hoznak. Megint mások finomabban fogalmaztak, miszerint a nagy választék a vásárlók számára nem nyújt többletelőnyt (Jacoby, 1977). A vásárlási döntés előzménye az információkeresés, ami a marketingtudomány számára gyakorlati és tudományos szempontból kulcsfontosságú (Bettman, 1979). A fogyasztói magatartás információkeresési definíciója szerint az információkeresés az a fogyasztói tevékenység, melyben a felmerült igény legtökéletesebb kielégítéséhez releváns adatokat gyüjtenek a termékről és használatáról. Guo (2001) megfogalmazásában az információkeresés a mind gyorsabban forgó és szélesebb termékkínálat, az internet és média által szolgáltatott nagy mennyiségü információ és a fogyasztói magatartás-változási tendenciák miatt még aktuálisabb, mint valaha. A fogyasztók a termék kiválasztása elött belső (memóriában elraktározott) és külső forrásból (reklám, eladóhelyi információ, barátok, ismerősök és szakemberek) származó információ alapján dönthetnek (Bauer-Berács, 2006). Moorman (1990; 1996) szerint az élelmiszerfogyasztók az informált döntés érdekében tájékozódnak, így az információkeresés vizsgálata élelmiszeripari termékek esetében magas relevanciával rendelkezik és érdekes kutatási téma. A fogyasztói információkeresés minden vásárlási döntés és választáshoz kapcsolódó magatartás alapja. Az információkeresés a vásárlási döntési folyamat részeként a marketing szakirodalomban folyamatosan a figyelem középpontjában van a 20. század eleje óta, és a fogyasztói magatartás könyvek elmaradhatatlan része (Copeland, 1923; Katona, Mueller, 1954), metaanalízisek sora jelent meg a témában (Newman, 1977; Guo, 2003).

Az élelmiszerek egyik terméktulajdonsága a címke, ami Caswell - Mojduszka (1996) szerint átjárást biztosít a különböző termék attribútumok között. A tápanyag információ jellemzően bizalmi információ, aminek szerepeltetése a terméken az információt kutathatóvá teszi, így a fogyasztók az értékesítés helyén össze tudják hasonlítani a különböző termékek tápértékét, és az alapján hozhatnak döntést. Chernew (2003) értelmezésében a választék mélységének vizsgálata fontos, amennyiben a fogyasztók vásárlás előtt csak annyit tudnak, hogy egy bizonyos termékkategóriát szeretnének megvenni, de a konkrét márkát még nem választották ki. A nagy kínálat (larger assortment) erősebb preferenciákat (stronger preferences) eredményez, és növeli a fogyasztók hasznosság érzetét, mert meghagyja a választás szabadságát, és csökkenti a bizonytalanságot, hogy az összes lehetséges változatot figyelembe vették-e a választás során, illetve hogy nincs még jobb alternatíva. Emellett nagyobb mentális munkát jelent az alternatívák értékelése miatt (Chernew, 2003). Az élelmiszerfogyasztási szokások kulturális különbségek miatt eltérnek, a fogyasztók eltérő módon és indokok miatt fogyasztanak élelmiszert, míg bizonyos társadalmakban az egészség megörzésének igénye alapján választanak, máshol kifinomult kulturális kifejezőeszköznek számít a táplálkozás (Wansink, 2005). Cleays és mtsai. (1995) valamint Lehota (2001) szerint az élelmiszerek két fö csoportba, a gondolkodási és érzelmi termékek csoportjába sorolhatók. A racionális döntések esetében az élelmiszerek tulajdonságai közül az ár, alapanyag, elérhetőség, csomagolás, választék, egészségügyi és táplálkozási értékek és élelmiszerbiztonság 
kap kiemelt szerepet, míg érzelmi döntések esetében a státusz, fiatalosság, sportosság, életstílus lehetnek befolyásoló tényezők (Lehota, 2001). Caswell (2006) gyüjtésében az élelmiszerek terméktulajdonságai egy komplexebb módon csoportosítva szerepelnek. A szerző a terméktulajdonságok két nagy csoportját, a külsőt (extrinsic) és a belsőt (intrinsic) különbözteti meg. A belső tulajdonságok keresési, tapasztalati vagy bizalmi információk, a külső tulajdonságok természetüknél fogva csak keresési tulajdonságok lehetnek. A külső jellemzők „Vizsgálható, és mérhető”csoportosításában találjuk a „Tanúsítás, Minősítés” fogalmakat. Szintén külső jellemző a „Jelölések” csoportjában szereplő „Ár, gyártó neve, Márka, Származási ország" fogalomkör. A termék eredetére vonatkozó besorolás Caswell (2006) szerint viszont már a belső jellemzők között, a „Folyamatorientált jellemzők” csoporton belül található.

\section{Anyag és módszer}

Primer kutatásunk során a hazai fogyasztók véleményére voltunk kíváncsiak, megismerve ezáltal a magyar termékekkel kapcsolatosan megnyilvánuló fogyasztói attitüdöket. Kutatásunk főbb kérdései a hazai fogyasztók vásárlási szempontjait, a termékinformációk, valamint élelmiszeripari védjegyek ismertségét, azok fogyasztói magatartást befolyásoló hatását, továbbá az etnocentrikus fogyasztói magatartásának mértékét, a termékek minőségének, árának szubjektív minőségi megítélését vizsgálták.

A kutatásban részt vevő fogyasztók száma 551 fő volt. Kutatásunkat a "MAGYAR TERMÉK" Nonprofit Kft. felkérésére - de általa anyagiakban nem támogatva - végeztük el. Munkánkat korlátozott lehetőségeink mentén ezért elsősorban a minőségre és nem a mennyiségre törekvés jellemezte. A megkérdezés módszere írásbeli megkérdezés (papír alapú kérdőív) volt. Kutatásunkat a Budapesti Gazdasági Egyetem hallgatói segítették a kérdőívek terjesztése során. A hallgatókat kértük, hogy a kérdőíveket a lehető legtágabb ismerősi körben terjesszék a széleskörü elérés érdekében. A felmérés során alkalmazott kérdőív tartalmi, valamint formai összeállításánál igyekeztünk törekedni a kérdések érthetőségére, az esetleges kétértelmüség kiszürésére és a sorrendiségre. A megkérdezettek személyi adatai teljes körü védelmet és anonimitást élveztek, személyes adataikat nem rögzítettük.

A kérdőív kitöltésében bárki részt vehetett, aki tényleges vásárlói tapasztalattal rendelkezett, és aktív résztvevője a fogyasztói piacnak. A kutatás során előzetes szelekciót nem alkalmaztunk, a mintába kerülésnél a véletlenszerüség dominált. Mintánk a lehetőségekből következően nem reprezentatív, de a minőségi törekvés jellemzi. Az eredmények a minta kiterjedtsége okán is jól használhatók. A hallgatók csupán a kérdőívek terjesztését segítették, a kitöltőknek a kitöltéshez segítséget nem nyújtottak. A kérdőívek feldolgozása az IBM SPSS program segítségével történt.

\section{Eredmények és értékelésük}

Kérdőíveink kitöltetésénél törekedtünk a nemek egyforma arányú megkérdezésére. Mivel a Budapesti Gazdasági Egyetem hallgatói segítették a kérdőívek terjesztését, 
ezért a lakóhely esetében dominánsan jelent meg Budapest. Ugyanezen okból a legmagasabb befejezett iskolai végzettség szerinti besorolás alapján a felsőfokú végzettséggel rendelkezők aránya volt a legnagyobb. Azonban számos kutatás (Klopp-McDonald, 1981; Moorman, 1990; Guthrie és mtsai., 1995; Nayga, 1997; Drichoutis és mtsai., 2005) szerint a végzettség pozitívan korrelál a címkehasználattal. A magasabb végzettségủek nagyobb valószínűséggel olvassák a címkét, mivel több előzetes tudással rendelkeznek, könnyebben interpretálják, de nem feltétlenül biztosak benne, hogy az alapján jobb élelmiszer-vásárlási döntést hoznak.

1. táblázat: A minta demográfiai megoszlása $(\mathbf{N}=551)$

\begin{tabular}{|c|c|c|}
\hline \multirow[t]{2}{*}{ Megnevezés } & \multicolumn{2}{|c|}{ Minta megoszlása } \\
\hline & Fö & $\%$ \\
\hline \multicolumn{3}{|c|}{ Nemek szerint } \\
\hline Nö & 269 & 48,82 \\
\hline Férfi & 282 & 51,17 \\
\hline \multicolumn{3}{|c|}{ Legmagasabb iskolai végzettség } \\
\hline Föiskola/egyetem & 255 & 46,27 \\
\hline Gimnázium & 163 & 29,58 \\
\hline Szakmunkásképző érettségivel & 83 & 15,06 \\
\hline Szakmunkásképzö, szakiskola érettségi nélkül & 36 & 6,53 \\
\hline Legfeljebb 8 általános & 14 & 2,54 \\
\hline \multicolumn{3}{|c|}{ Lakóhely településtípusa } \\
\hline Község & 48 & 8,71 \\
\hline Város & 131 & 23,77 \\
\hline Megyeszékhely & 85 & 15,42 \\
\hline Budapest & 287 & 52,08 \\
\hline \multicolumn{3}{|c|}{ Elégedett-e a jövedelmével? } \\
\hline Egyáltalán nem & 31 & 5,62 \\
\hline Nem & 155 & 28,13 \\
\hline Nagyjából & 318 & 57,71 \\
\hline Nagyon & 47 & 8,52 \\
\hline \multicolumn{3}{|c|}{ Ki végzi a napi fogyasztási cikkek bevásárlását? } \\
\hline Csak valaki más & 52 & 9,43 \\
\hline A megkérdezett és valaki más & 250 & 45,37 \\
\hline Csak a megkérdezett maga & 249 & 45,19 \\
\hline
\end{tabular}

Forrás: saját szerkesztés, $2017(\mathrm{~N}=551)$

A megkérdezettek több mint fele volt nagyjából elégedett a jövedelmi helyzetével, és $90 \%$-uk végezte egyedül, vagy többedmagával a bevásárlást.

A kérdőív összeállításakor logikai sorrendiségre törekedtünk. Az első kérdésekkel a válaszadók vásárlási szokásait, a termékinformációk használatát, a termékek származási helyéhez, és a magyar termékekhez kapcsolódó attitüdjét vizsgáltuk. A második kérdéskör a védjegyek ismeretére irányult, a kérdöív utolsó kérdéseivel pedig az etnocentrikus fogyasztói magatartást vizsgáltuk. 


\section{1. ábra: Milyen gyakran olvassa el a termékcsomagoláson található termékinformációkat?}

A termék gyártóját

A termékösszetevöket

A termék származási helyét

A termék minőségét

A márkát

A termék árát

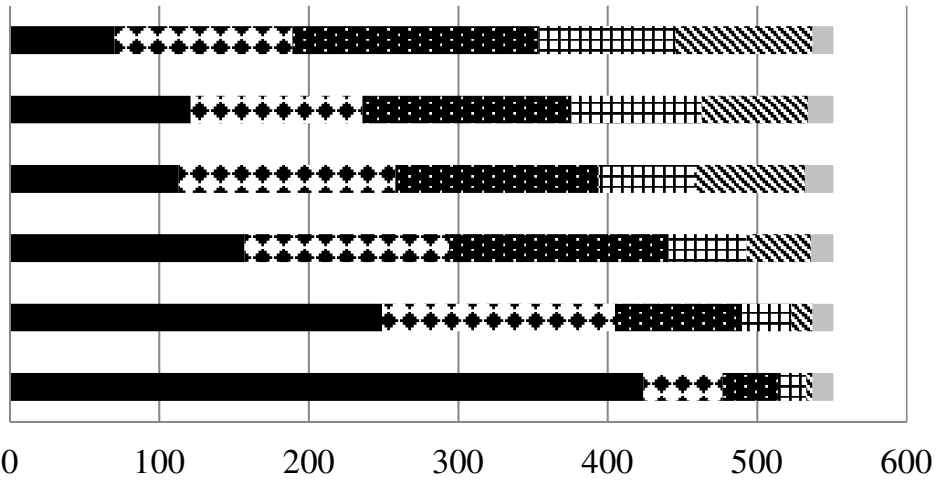

- gyakran

- néha

- mielött először vásárolom a terméket

s nem figyelem + néhány terméknél figyelem

$\square \mathrm{NT} / \mathrm{NV}$

Forrás: saját szerkesztés, 2017 (N=551)

A válaszadók 48\%-a figyeli a termék származási helyét: $22 \%$ mindig figyeli, $26 \%$ pedig mielőtt először vásárolja a terméket. A termék ára esetében ugyanez az arány $87 \%$ volt. A megkérdezettek $14 \%$-a egyáltalán nem figyeli a csomagoláson található termékinformációk közül a termék származási helyét.

\section{2. ábra: Megnézi-e a származási helyet élelmiszer vásárláskor?}

(a megkérdezettek százalékában)

Az említés gyakorisága (\%)

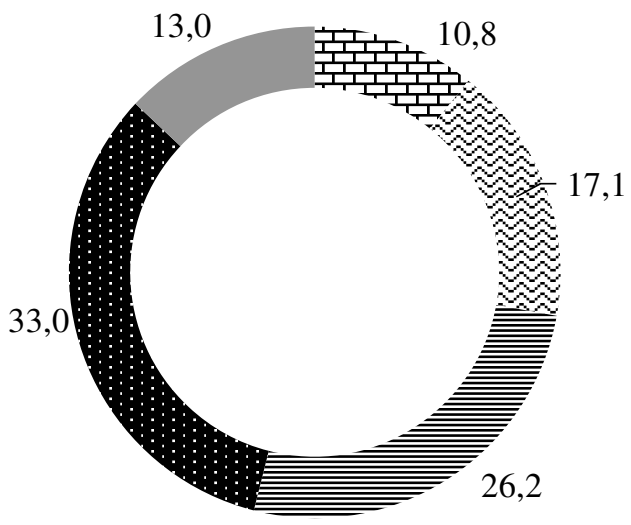
× Mindig, minden termék esetében elolvasom
צ Mielőtt elöször vásárolnék egy terméket mindig elolvasom
三Az esetek többségében elolvasom
- Csak bizonyos esetekben olvasom el
Sosem olvasom el

Forrás: saját szerkesztés, 2017 (N=551) 
A válaszadók $46 \%$-a csak bizonyos esetekben, vagy sosem olvassa el a vásárolt termék származási helyét. A megkérdezettek $28 \%$-a mindig, minden termék esetében elolvassa (11\%), illetve mielőtt először vásárol egy terméket, mindig elolvassa (17\%) a termék származási helyével kapcsolatos információkat.

A termék származási helyével kapcsolatos fogyasztói attitüd alaposabb megismeréséhez nyitott kérdéseket tettünk fel a kérdöívet kitöltőknek, melyben lehetőségük volt a termékek származási helyére vonatkozó szempontjaik saját szavukkal történő megindokolására. Az „Amennyiben a termék származási helyét nem mindig figyeli vagy csak néhány terméknél figyeli, mi ennek az oka?" kérdésre a válaszadók nagyon különböző válaszokat adtak. Legnagyobb okozója a termék származási helyének figyelmen kívül hagyásának az ár volt, ezt 53 fó választotta okként. Ezzel szemben 49 fő válaszolta indok nélkül csak azt, hogy nem figyeli a származási helyet. Azok közül, akik figyelik vásárlásuk során a termék származási helyét, a legtöbben ezt a minőséggel (28 fö), illetve különböző termékcsoportok származási helyének jelentőségével indokolták. Csak 24 fő válaszolta azt, hogy a magyar származási hely jelentősége miatt vizsgálja a feltüntetett származási helyet a termékeken. Ezen kívül csak nagyon elenyésző számban írtak fel más tényezőket. Ilyen volt például az időhiány ( 9 fö), az íz (6fö), jobb minőség (3fö), megbízhatóság (1 fö). A következő nyitott kérdés azoknak a termékcsoportoknak a megismerésére irányult, amelyeket a válaszadók a származási hely szempontjából fontosnak tartottak. A „Ha csak néhány terméknél figyeli a származás helyét, melyek ezek a termékek" kérdésre adott szöveges válaszok a legnagyobb számban a friss termékeket hangsúlyozták ki. A tejtermékeket említették meg a megfigyelt termékek között a legtöbben (59 fö). Ezen belül kiemelték magát a tejet (36 fö), illetve a sajtokat (5 fö). A gyümölcsök és zöldségek voltak a második származási hely alapján legtöbbet vizsgált termékek. A gyümölcsöt (57 fö) választotta, szorosan követve a zöldségtől (54fö). A harmadik helyen a húsok álltak a válaszadók száma alapján. Összesen 26 fö vizsgálja a származási helyet ennél a termékcsoportnál, ezen belül 16 fő a friss húsnál, 8 fő pedig a felvágottaknál. Összesen 20 fö válaszolta az élelmiszerek csoportját, anélkül, hogy bármelyik említett kategóriát kiemelte volna. Itt is voltak kis számban elöforduló válaszok, például a ruha (9fö), elektronikai eszközök (10 fö), csokoládé (5 fö). 


\section{3. ábra: Előnyben részesíti-e a magyar élelmiszereket a külföldivel szemben? (a megkérdezettek százalékában)}

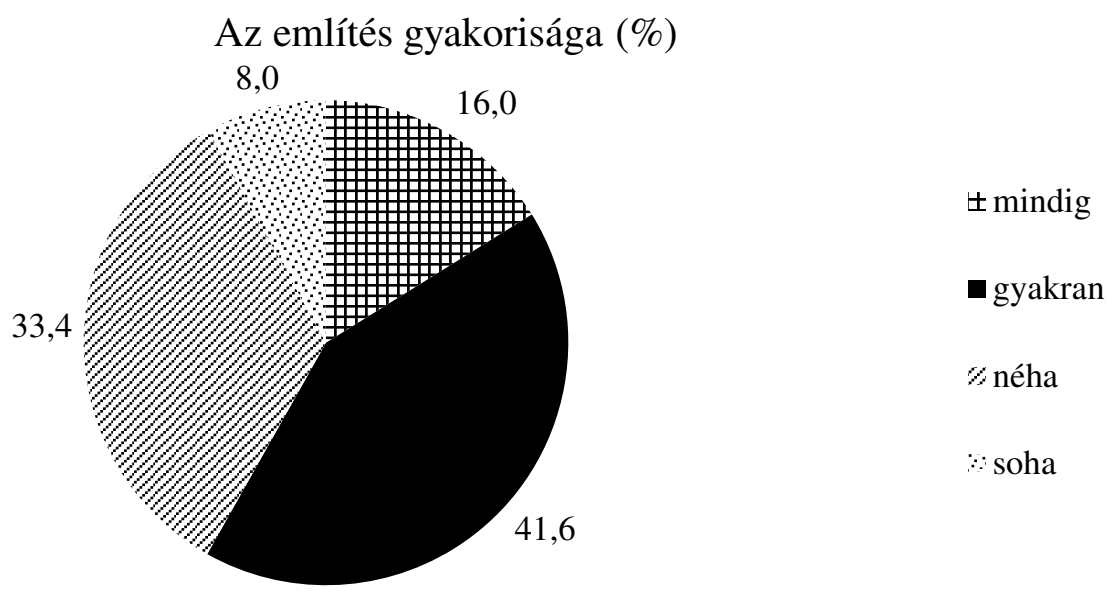

Forrás: saját szerkesztés, 2017 (N=551)

A megkérdezettek mindössze $8 \%$-a válaszolta azt, hogy soha nem részesíti elönyben a hazai élelmiszereket a külföldi termékekkel szemben. A válaszadók 57,6\%-a mindig, vagy gyakran preferálja a magyar termékek vásárlását. A következő kérdéssel ennek az előnyben részesítésnek a fogyasztói motivációit vizsgáltuk.

\section{4. ábra: Amennyiben előnyben részesíti a magyar termékeket, mi ennek az oka?}

\section{Említés gyakorisága (\%)}

Mert ezzel a magyar gazdaságot támogatom

Mert hazai munkahelyeket teremthet

Mert jobb a minőségük

Ezt szoktam meg

Megéri az árát

Nagyobb biztonságot jelent

Kedvezőbb az ára

NT/NV

Divat magyar termékeket vásárolni

Egyéb
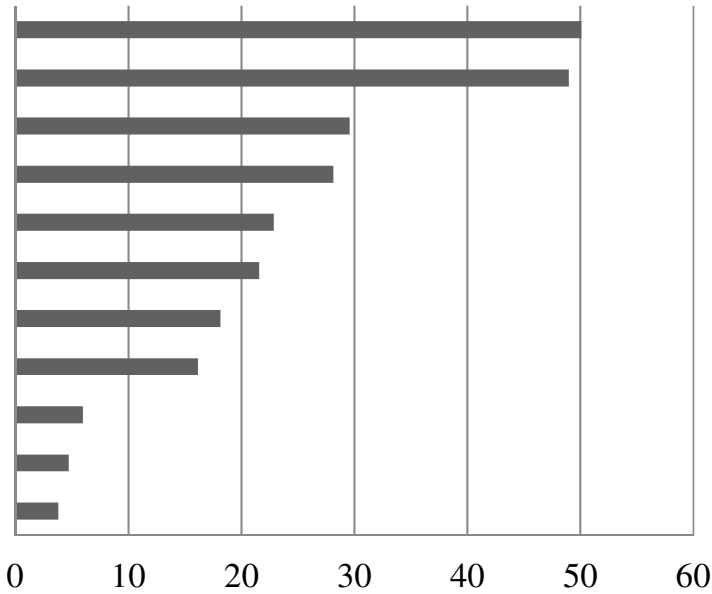

Forrás: saját szerkesztés, 2017 (N=551) 
A válaszadók, amennyiben előnyben részesítik a magyar termékeket, az „Ismerem az eredetét”, és „Mert ezzel a magyar gazdaságot támogatom” okokat kiugró mértékben választották: a válaszadók fele jelölte meg ezeket az okokat. Az, hogy „,nagyobb biztonságot jelent”, „kedvezőbb az ára” vagy „divat magyar termékeket vásárolni" a legkevésbé elismert szempontok.

\section{5. ábra: Általában mennyire veszi figyelembe a következő szempontokat élelmiszer vásárláskor? (a megkérdezettek százalékában)}

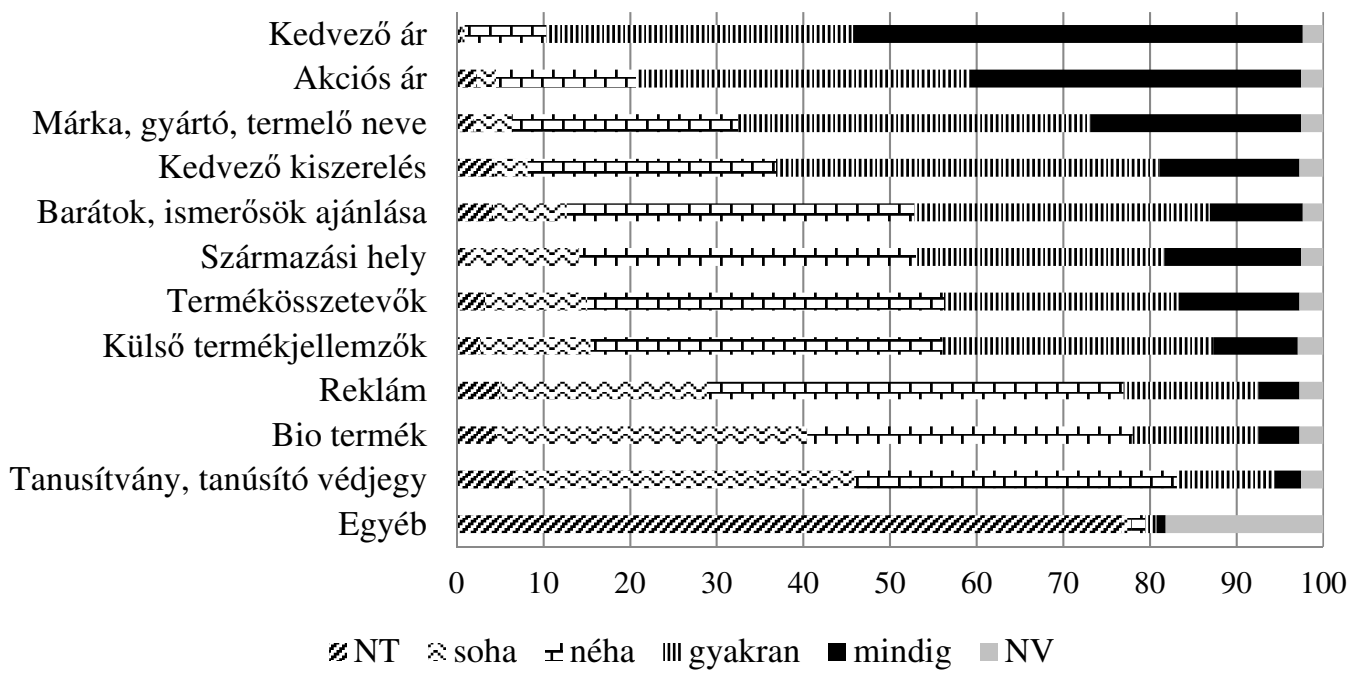

Forrás: saját szerkesztés, $2017(\mathrm{~N}=551)$

A válaszadók közel fele veszi figyelembe a származási helyet, azonban a tanúsítványok, tanúsító védjegyek figyelembe vétele alacsony mértékü: 3,1 \% mindig, $11,3 \%$ pedig gyakran figyelembe veszi vásárlásai során. A válaszadók 39,6\%-a sohasem veszi figyelembe a védjegyeket, amikor élelmiszereket vásárol.

A védjegyek a származás tanúsítására (pl. magyar összetevő mennyiségére), illetve a minőségre/ellenőrzés tényére adnak garanciát a fogyasztó számára; már amennyiben a fogyasztó tisztában van a jelölés tényleges jelentéstartalmával. A védjegyeknek a marketingben számos, azonban egymástól lényegében nem eltérö definíciója létezik. A védjegy az áruk vagy szolgáltatások megkülönböztetésére szolgáló olyan jelzés vagy megjelölés, amelynek használata kizárólagos jelleggel csak a védjegyoltalom jogosultját illeti meg (Lontai és mtsai., 2012). Atkin (2004) szerint a márkák és a védjegyek olyan üzenetet sugároznak, amelyek kifejezik és reagálnak az értékeinkre, az énképünkre, vágyainkra. George (2006) értelmezésében a márkák, védjegyek segítségével különlegesnek érezhetjük magunkat és egyúttal a hovatartozásunkat is kifejezzük velük. A védjegy alapvetően a származásra utal, egyfajta garanciaként szolgál arra, hogy a termék vagy szolgáltatás egy adott forrásból származik és egy bizonyos minőségi szintet elér (Aboluian-Charnley, 2007). Az 1997. évi XI. törvény II. Fejezet 12. § (1), 101.§ (1) bekezdése szerint a védjegy olyan jel, ami megkülönböztet egy árut vagy szolgáltatást a versenytársak 
más, hasonló, vagy akár azonos tartalmú termékeitől, azonban nem kötelező eleme az élelmiszerek címkéjének. Védjegy lehet egy név, logó, ábra, szó, szlogen, betü, szám, kép, hologram, szín, vagy ezeknek a kombinációja. ”A védjegyoltalom alapján a védjegyjogosultnak kizárólagos joga van a védjegy használatára". A védjegyek alkalmazása nem csupán a fogyasztók számára előnyös. Azok a vállalkozások, amelyek a védjegyet (származást, minőséget) sikeresen tudatosítják a vásárlókban, versenyelönyre tehetnek szert konkurenseikhez képest. Totth és mtsai., (2015) szerint a piaci verseny, valamint a hatalmas kínálat közepette a névtelen, nem pozícionált, önálló karakterrel nem rendelkező termékek és vállalkozások hátrányba kerülnek.

A tanúsító védjegyet sok esetben összekeverik a földrajzi árujelzőkkel. A földrajzi árujelzőknek két típusa van: 1.: A földrajzi jelzés: A földrajzi jelzés valamely táj, helység, kivételes esetben ország neve lehet, amelyet ez erről a helyről származó, tehát ezek a földrajzi területen termelt, feldolgozott vagy előállított olyan termék megjelölésére használnak, amelyek különleges minősége, hírneve vagy egyéb jellemzője kifejezetten ennek a földrajzi származásnak tulajdonítható. Pl.: Makói Hagyma. Vecsési Káposzta. 2.: Eredet jelzés: Az eredet jelzés valamely táj, helység, kivételes esetben ország neve lehet, amelyet ez erről a helyről származó, tehát ezek a földrajzi területen termelt, feldolgozott vagy előállított olyan termék megjelölésére használnak, amelyek különleges minősége, hírneve vagy egyéb jellemzője kizárólag vagy lényegében az adott földrajzi környezet, az arra jellemző természeti és emberi tényezők következménye. Pl.: Hungaricum. A földrajzi árujelzőket főként a mezőgazdasági és az élelmiszeripari termékek esetén alkalmazzák, mert általában ezek esetén érvényesülnek tisztán és kizárólag a földrajzi környezetből fakadó egyedi jellegek. Valójában a földrajzi árujelzők is felfoghatók egyfajta tanúsító védjegynek, azzal a korlátozással, hogy a földrajzi árujelzők esetén az egyedi jelleg kizárólag az adott földrajzi hely természeti és emberi tényezőire vezethető vissza. Míg a tanúsító védjegyek esetén a megkülönböztető jelleg bármilyen előre meghatározott minőségi vagy egyéb jellemzőből származtatható. (Magyar Termék Nonprofit Kft.) 


\section{6. ábra: Általában mennyire veszi figyelembe a következő szempontokat élelmiszer vásárláskor? (gyakran és mindig válaszok a megkérdezettek százalékában)}

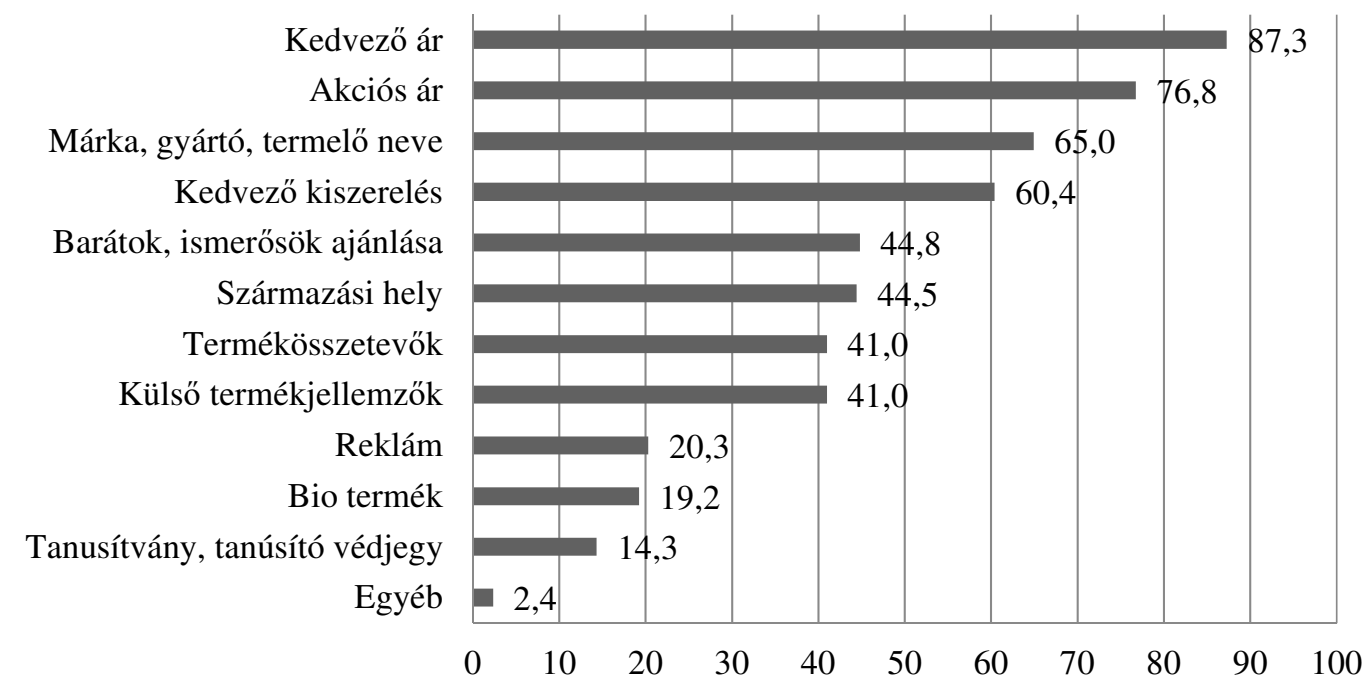

Forrás: saját szerkesztés, $2017(\mathrm{~N}=551)$

A megkérdezettek körében szignifikáns eltérés van azok között, akik figyelembe veszik a termék eredetét, és akik nem veszik figyelembe. Amennyiben fontos az élelmiszer eredete, akkor főként kis élelmiszerboltban, szaküzletben, piacon, vagy közvetlenül a termelötől vásárolnak.

$\mathrm{Az}$ élelmiszeripari termékeken található tanúsító védjegyek ismertségének mértékéhez, és a védjegyekhez kapcsolódó fogyasztói attitüd alaposabb megismeréséhez nyitott kérdéseket tettünk fel a kérdőívet kitöltőknek. A „Milyen tanúsító védjegyeket ismer?" nyitott kérdésre adott válaszokból kiderült, hogy a válaszadók legtöbbje nem tudta értelmezni a tanúsító védjegy fogalmát. Legtöbben márkákat írtak a kitöltendő mezőkbe, sokan főként külföldi élelmiszer márkákat (Coca-Cola, Univer stb.). Felsorolásaikban magyar márkák is előfordultak, leggyakrabban ezek közül a Pick-et (60 fö), a Mizot (20 fö), a Pöttyöst (15 fö), a Szentkirályit (12 fö) és a Cserpest (10 fö) említették.

A tényleges tanúsítói védjegyek sorában első helyen a Magyar Termék szerepelt. Összesen 159 fő írta ezt bele a felsorolásba. A második helyen a Hazai Termék védjegy szerepelt, 74 válaszadó leírásában. A többi védjegyet a válaszadók már csak egy töredéke ismerte. A válaszok között 28 -szor szerepeltek a bio védjeggyel jelzett termékek. Ezután következett a Superbrands (24 fö), Szívbarát (22 fö), Magyar Baromfi (17 fö), Magyar Brands (13 fö). A kérdés válaszai között ismert magyar termelöi márkák is szerepeltek, Gyulai (26 fö), Csabai (11fő). 


\section{7. ábra: Ön melyeket ismeri vagy figyeli vásárlásai során? Ha jó minőségü} hazai élelmiszert szeretne vásárolni, mit nézne meg a termék csomagolásán? kérdésekre adott válaszok (a megkérdezettek százalékában)

Ismert magyar termelői márkák

Magyar Baromfi

Szívbarát

Superbrands

Kiváló Magyar Élelmiszer

Közvetlenül a termelőtől vásárolok

Hazai Feldolgozású Termék

Magyar Brands

Méz-zárszalag, mézesüveg

Tejszív

Magyar Termék Nagydíj

Prémium Hungaricum

Oltalom alatt álló eredetmegjelölés

Oltalom alatt álló földrajzi jelzés

599-el kezdődő vonalkód

Kiváló Áruk Fóruma

Hagyományos és különleges termék

Hagyományok, ízek, régiók (HIR)

A gyártó személyes szavatolása

Nemzeti Parki Termék

\# nem ismeri
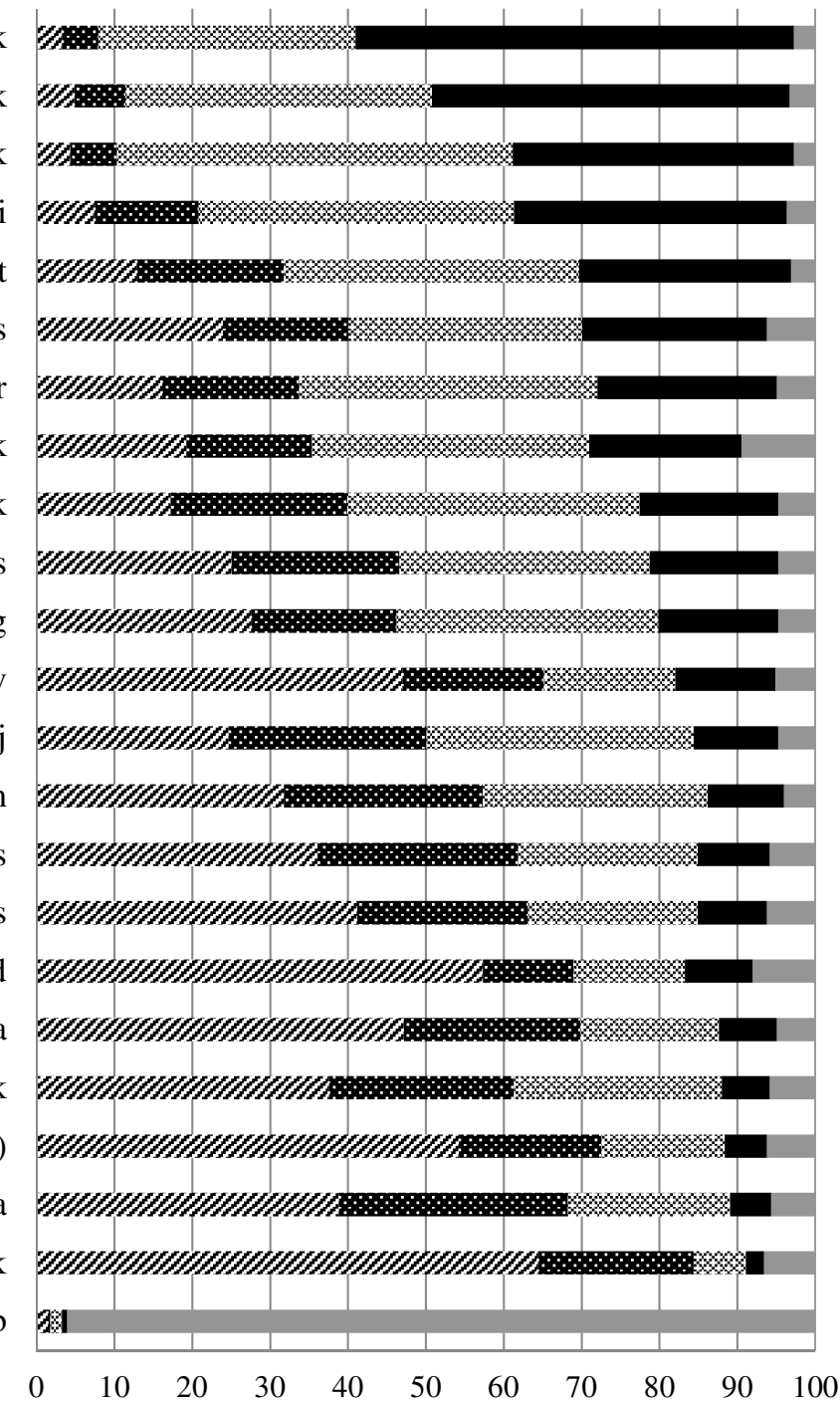

Ismeri, de még nem vásárolt ilyen terméket

\$ Ismeri, vásárolt már ilyen terméket

— ismeri, rendszeresen vásárol ilyen terméket

$\square \mathrm{NT} / \mathrm{NV}$

Forrás: saját szerkesztés, $2017(\mathrm{~N}=551)$ 
8. ábra: A vásárlók legalább fele ismeri és rendszeresen vásárolja, vagy vásárolt már olyan terméket, amelyeken a következő jelölések szerepelnek (a megkérdezettek százalékában)

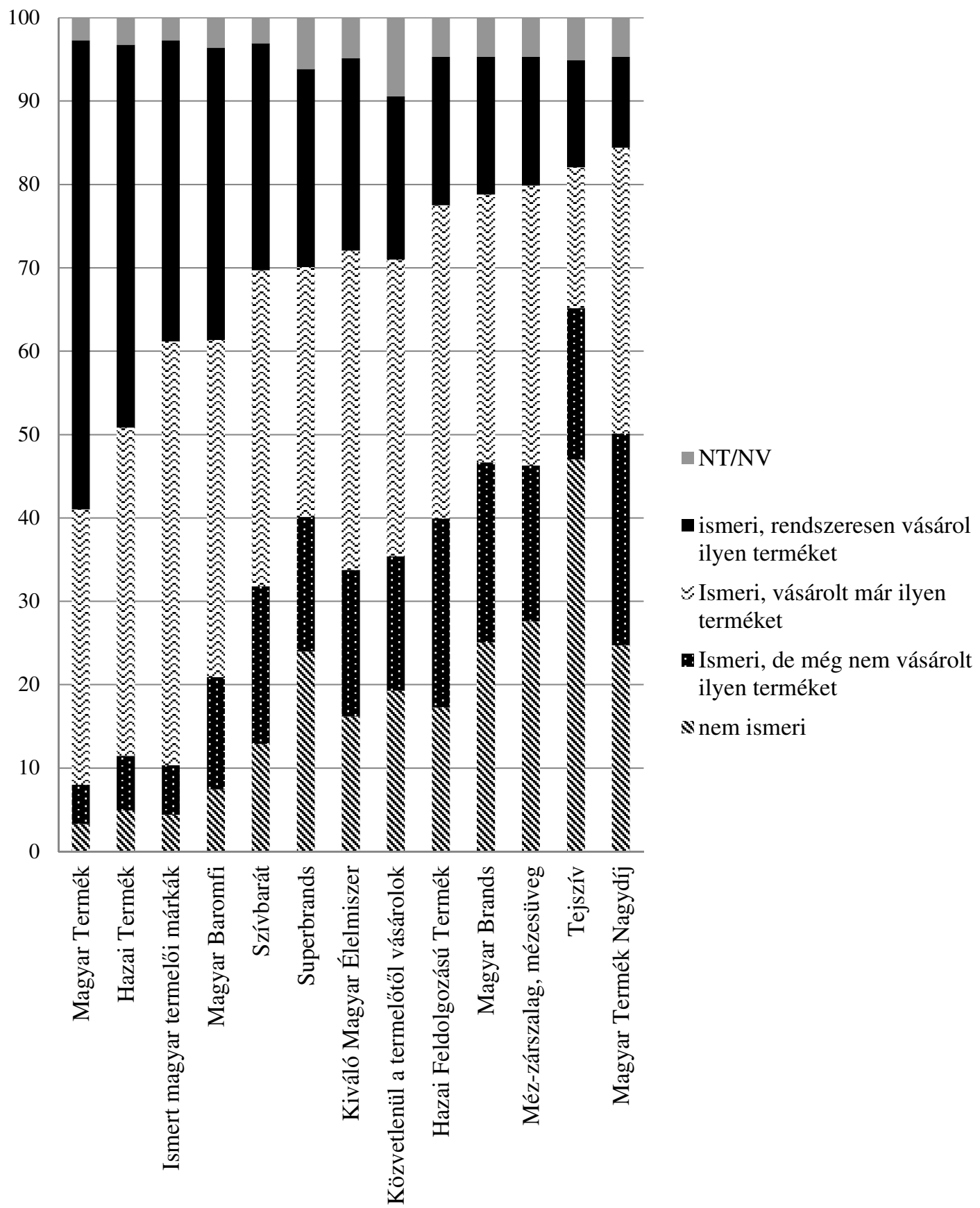

Forrás: saját szerkesztés, $2017(\mathrm{~N}=551)$ 
9. ábra: Ha jó minőségủ hazai élelmiszert vásárolna, a következőket figyelné (a megkérdezettek százalékában)

Ismeri, rendszeresen vásárol ilyen terméket (\%)

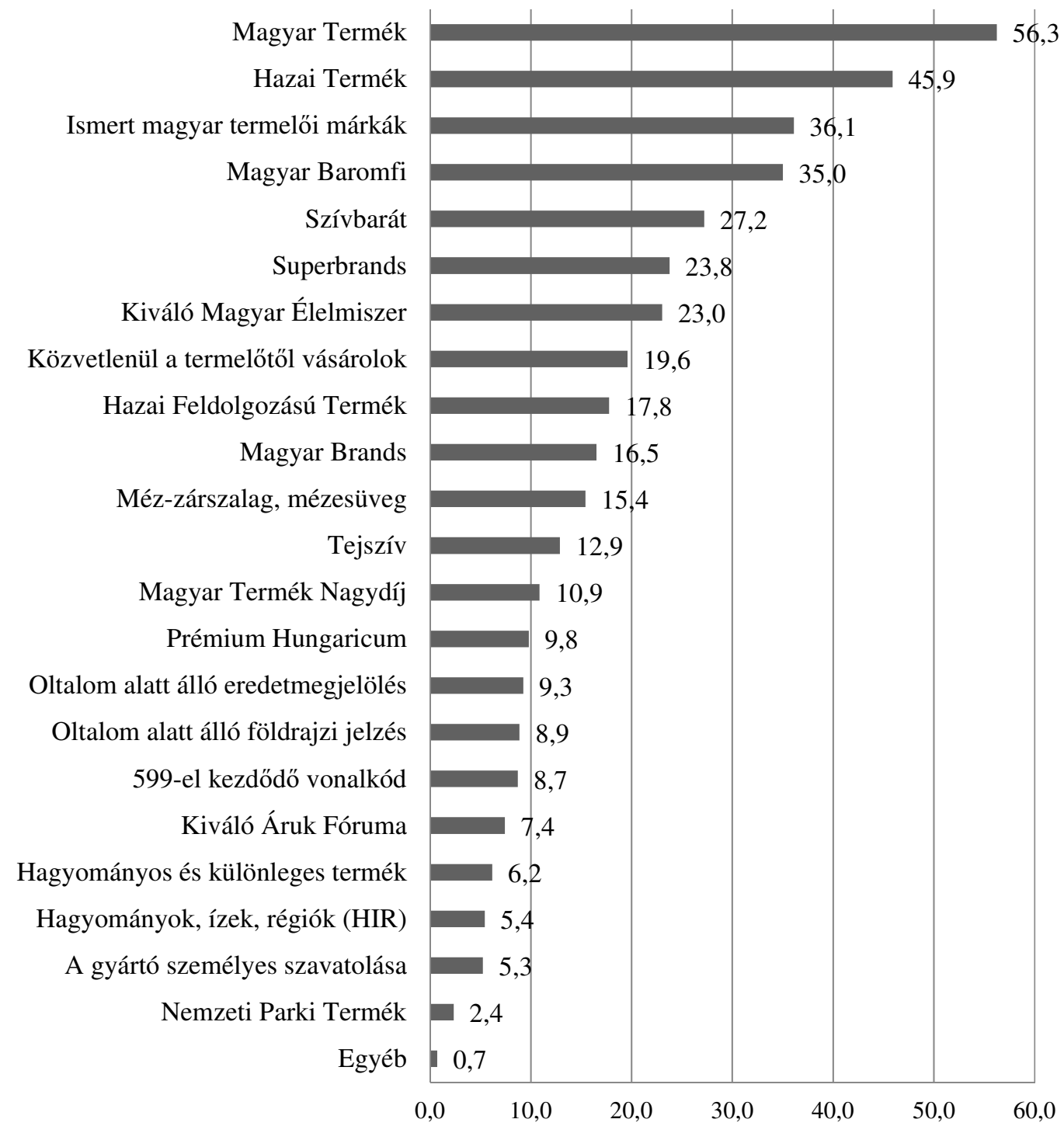

Forrás: saját szerkesztés, $2017(\mathrm{~N}=551)$

A jó minőségü hazai élelmiszer vásárlására irányuló kérdés esetében a megkérdezettek 94\%-a ismerte a Magyar Termék védjegyeket. A Magyar Termék védjeggyel ellátott termékek 100\%-osan magyar alapanyagból, Magyarországon készülnek. Élelmiszer esetében ez azt jelenti, hogy az állatot hazánkban nevelték fel, a növényt Magyarországon termesztették, a feldolgozás minden lépése hazánkban történt, a felhasznált alapanyagok Magyarországról származnak, az összetevők körében kivételt csak az adalékanyagok, füszerek és a só jelenthet. 
A vidékfejlesztési miniszter 74/2012. (VII. 25.) VM rendelete - az egyes önkéntes megkülönböztető megjelölések élelmiszereken történő használatáról alapján lényegében csak azon termékek tekinthetők „magyar terméknek”, amelyek 100\%-ban magyar alapanyagból (növényi eredetủ termék esetében a felhasznált növényeket hazánkban termesztik, takarítják be; állati eredetủ termék esetében az állat hazánkban született, itt keltették, nevelték, stb.) Magyarországon készültt. Kevésbé szigorú feltételek szükségesek a „hazai termék” kategóriának való megfeleléshez: ebben az esetben a termék összetevőknek legalább 50\%- ban kell megfelelniük a magyar termékkel szemben támasztott követelményeknek, illetve a feldolgozás minden lépésének Magyarországon kell megtörténnie. Létezik egy további kategória is, amely részben utal arra, hogy a terméknek van magyarországi kötődése, ebben az esetben „hazai feldolgozású termékröl” beszélünk. Ilyenkor a termék Magyarországon kerül feldolgozásra, minden olyan eljárást magában foglalva, ami a termék összetételét vagy érzékszervi tulajdonságait megváltoztatja, de összetevőit tekintve az import lesz a domináns. Mára a termelők/előállítók a fenti szabályt ismerik, hiszen kénytelenek voltak megismerni azokat.

\section{0. ábra: A Magyar Termék védjeggyel ellátott termék a többi termékkel összehasonlítva ....}

Hitelesebb, mert független fél által ellenőrzött

Környezetvédelmi szempontból előnyösebb

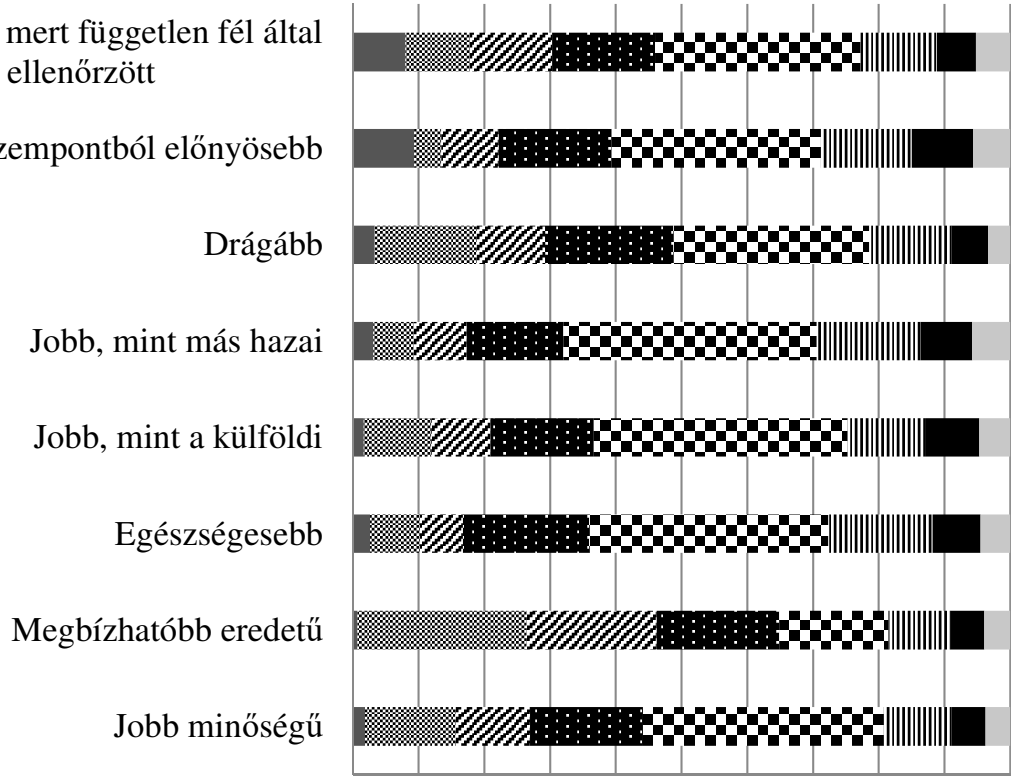

nT/NV

$\approx 6$

$n$ Egyet is értek meg nem is

- 2
0\% 10\% 20\% 30\% 40\% 50\%60\% 70\% 80\% 90\% $100 \%$ Teljesen egyetértek

$$
\begin{aligned}
& \text { a } 5 \\
& \text { IIII } 3 \\
& \square \text { Egyáltalán nem értek egyet }
\end{aligned}
$$

Forrás: saját szerkesztés, $2017(\mathrm{~N}=551)$ 


\section{2. táblázat: Top3*: azok aránya (\%), akik inkább egyetértenek - nagyon} egyetértenek az állításokkal, miszerint a Magyar Termék védjeggyel ellátott termék a többi termékkel összehasonlítva... (egyetértés: 5, 6, 7 értékei)

\begin{tabular}{|c|c|c|}
\hline & Top3* & Átlag \\
\hline Jobb minőségü & 49,9 & 4,59 \\
\hline Megbízhatóbb eredetü & 71,3 & 5,08 \\
\hline Egészségesebb & 43,9 & 4,24 \\
\hline Jobb, mint a külföldi & 46,5 & 4,31 \\
\hline Jobb, mint más hazai & 41,4 & 4,16 \\
\hline Drágább & 53,0 & 4,70 \\
\hline Környezetvédelmi szempontból elönyösebb & 43,7 & 4,44 \\
\hline Hitelesebb, mert független fél által ellenörzött & 37,0 & 4,71 \\
\hline
\end{tabular}

Forrás: saját szerkesztés, $2017(\mathrm{~N}=551)$

A hazai élelmiszereket mindig vagy gyakran és a néha választók között szignifikáns eltérés van a következö állításokkal való egyetértés alapján: A Magyar Termék védjeggyel ellátott termék a többi termékkel összehasonlítva: - jobb minőségü; - megbízhatóbb eredetü; - egészségesebb; - jobb, mint a külföldi; - jobb, mint más hazai; - hitelesebb, mert független fél által ellenőrzött. A drágább, illetve környezetvédelmi szempontból előnyösebb válaszok között nincsen meghatározó különbség.

\section{3. táblázat: A hazai élelmiszereket mindig vagy gyakran és a néha választók} közötti eltérés a következő állításokkal való egyetértés alapján

\begin{tabular}{|c|c|c|c|c|c|}
\hline & & egyetért & semleges & top3 & szign \\
\hline \multirow{2}{*}{ Jobb minőségü } & gyakran vagy mindig & $15.9 \%$ & $32,4 \%$ & $51,7 \%$ & \multirow{2}{*}{ igen } \\
\hline & néha & $26,9 \%$ & $47,4 \%$ & $25,7 \%$ & \\
\hline \multirow{2}{*}{ Megbízhatóbb eredetü } & gyakran vagy mindig & $15,5 \%$ & $13,5 \%$ & $71,0 \%$ & \multirow{2}{*}{ igen } \\
\hline & néha & $24,9 \%$ & $23,2 \%$ & $52,0 \%$ & \\
\hline \multirow{2}{*}{ Egészségesebb } & gyakran vagy mindig & $22,3 \%$ & $37,5 \%$ & $40,1 \%$ & \multirow{2}{*}{ igen } \\
\hline & néha & $40,5 \%$ & $37,0 \%$ & $22,5 \%$ & \\
\hline \multirow{2}{*}{ Jobb, mint a külföldi } & gyakran vagy mindig & $19,5 \%$ & $40,7 \%$ & $39,8 \%$ & \multirow{2}{*}{ igen } \\
\hline & néha & $36,4 \%$ & $36,4 \%$ & $27,3 \%$ & \\
\hline \multirow{2}{*}{ Jobb, mint más hazai } & gyakran vagy mindig & $24,9 \%$ & $39,7 \%$ & $35,4 \%$ & \multirow{2}{*}{ igen } \\
\hline & néha & $41,1 \%$ & $40,0 \%$ & $18,9 \%$ & \\
\hline \multirow{2}{*}{ Drágább } & gyakran vagy mindig & $22,8 \%$ & $30,9 \%$ & $46,2 \%$ & \multirow{2}{*}{ nem } \\
\hline & néha & $20,8 \%$ & $30,6 \%$ & $48,6 \%$ & \\
\hline \multirow{2}{*}{$\begin{array}{l}\text { Környezetvédelmi } \\
\text { szempontból } \\
\text { előnyösebb }\end{array}$} & gyakran vagy mindig & $28,9 \%$ & $37,2 \%$ & $33,8 \%$ & \multirow[b]{2}{*}{ nem } \\
\hline & néha & $37,5 \%$ & $30,6 \%$ & $31,9 \%$ & \\
\hline \multirow{2}{*}{$\begin{array}{l}\text { Hitelesebb, mert } \\
\text { független fél által } \\
\text { ellenörzött }\end{array}$} & gyakran vagy mindig & $19,8 \%$ & $33,6 \%$ & $46,5 \%$ & \multirow[b]{2}{*}{ igen } \\
\hline & néha & $34,8 \%$ & $34,8 \%$ & $30,4 \%$ & \\
\hline
\end{tabular}

Forrás: saját szerkesztés, $2017(\mathrm{~N}=551)$

A kérdőív utolsó kérdéseivel az etnocentrikus fogyasztói magatartást vizsgáltuk. Sok fogyasztó nem támogatja a külföldön termelt áruk beszerzését. Ez a magatartás 
fogyasztói etnocentrizmus néven vonult be a szakirodalomba. Sumner (1906) etnocentrizmus fogalma alapján ezt a jelenséget Shimp-Sharma (1987) definiálta.

Az etnocentrizmusra vonatkozó kutatások esetében a társadalmi elfogadhatóság áll a középpontban. Huddleston és mtsai. (2001) szerint ebben az esetben a származási hely egy külső minőségjelzőként müködik a fogyasztó számara a fogyasztói döntési folyamat során, amely értékelése az etnocentrizmus által befolyásolt. Lehota - Fürediné (2007) szerint az elmúlt években a megszaporodott élelmiszer-biztonsági botrányok miatt, megnövekedett az etnocentrizmus, mint kockázatredukciós tényező jelentősége, melynek köszönhetően a fogyasztók a nyomon követhető helyi élelmiszereket preferálják.

A magyarországi fogyasztói etnocentrizmus erősödése az elmúlt tizenöt évben vált markánssá. Papadopoulos és mtsai. 1990-ban végzett nemzetközi felmérése alapján a magyar fogyasztók még jóval szívesebben vásároltak külföldi termékeket, és a hazai termékek minőségét alacsonyra értékelték. Egy 1993-ban végzett, nyolc országra kiterjedő felmérés alapján a magyarok voltak az egyetlenek, akik nem a saját hazai termékeket vásárolják leggyakrabban és nem azokkal elégedettek leginkább (Papadopoulos és mtsai., 1993). 2000-ben az IKON kutatócsoport 15 országra kiterjedő vizsgálata a magyar fogyasztói attitüdöt - az indonézzel együtt élesen elkülönülőnek mutatja más országok fogyasztóihoz képest, mivel a válaszok a magyar termékeket a legtöbb szempont tekintetében kevésbé kedvezően értékelték. Egy 2003-ban végzett reprezentatív kutatás eredménye alapján az 500 megkérdezett budapesti személy válasza szerint a termékek minőségi paramétereit illetően a magyar termékek a német és kanadai termékek mögé kerültek, viszont megelőzték a cseh termékeket, idézi Malota (2011). Szintén ő fogalmazta meg azt a hazai trendet, miszerint a magyar márkák 'cikisből' népszerüvé váltak. Az elmúlt években számos kutatás készült a tanúsító védjegyek fogyasztói megítélésének vizsgálatára. 2010ben Szakály és mtsai. (2010) a tanúsító védjegyekkel kapcsolatos fogyasztói attitüdöt és védjegyekhez való viszonyt a fogyasztói etnocentrizmus szemszögéből elemezték. A szerzők kutatási eredményei arra utaltak, hogy mind a fogyasztói etnocentrizmus, mind pedig a védjegyek vásárlási döntést befolyásoló szerepe, illetve ezek fontossága messze elmarad az árak döntést befolyásoló szerepétől. Miskolczi (2011) szerint bizonyos áruházláncok elkezdték kiemelni reklámújságjaikban, akciós katalógusaikban a termék magyar voltát. A „magyar” mint termékjelző alkalmazása napjainkban divatos marketingeszközzé vált Magyarországon. A Nielsen piackutató intézet 2010-es felmérése szerint minden második magyar számára fontos szempont az élelmiszerbiztonság. A felmérés szerint tíz magyar közül hatan biztonságosnak tartják a megszokott üzletükben vásárolt élelmiszereket, és minden második számára fontos szempont az élelmiszerbiztonság az üzlet kiválasztásakor. A megkérdezett magyarok fele hajlandó magasabb árat fizetni a biztonságosan fogyasztható élelmiszerért. A magyarok többsége (58\%) véli azt, hogy az itthon termelt élelmiszer biztonságosabb, mint az import, és $53 \%$-a aktívan keresi az üzletekben a hazai termékeket (http://pmsz.org/hu/kutatasok/fogyaszt\%C3\%B3i-bizalom-\%C3\%A9s-\%C3\%A9le lmiszerbiztons C3\%A1g) 
A GfK Hungária felmérése szerint a vásárlók számára egyre fontosabb az áruk magyar eredete. A megkérdezettek 68\%-a számára fontos, hogy a termék magyar eredetü legyen (http://www.gfk.com/imperia/md/content/gfk_hungaria/pdf/ press_h/press_20090507\%20_h.pdf)

A fogyasztói etnocentrizmus mérésére 1987-ben Shimp-Sharma kidolgozott egy 17 állítást tartalmazó skálát. A Consumer Ethnocentric Tendency Scale (CETSCALE), a marketing-szakirodalomban az egyik leggyakrabban alkalmazott és legelfogadottabb skála. 180 állításból, többszörös tesztelés során választották ki a legvégső 17 állítást, majd ezt a 17 skálaváltozót négy mintán empirikusan tesztelték. A CETSCALE a fogyasztók hiedelmeinek, attitüdjeinek, a vásárlási szándéknak és a fogyasztói választásnak a magyarázatára lett létrehozva. Létrehozói azonban hangsúlyozták, hogy a skála tendenciát mér, nem pedig attitüdöt (Jiménez-Guerrero és mtsai., 2014).

$\mathrm{Az}$ etnocentrikus fogyasztói magatartás megismerésére irányuló kérdések összeállításánál nem használtuk fel mind a 17 CETSCALE állítást, valamint néhány állítás esetében apró változtatást alkalmaztunk az eredeti skálához képest. 


\section{1. ábra: Mennyire ért egyet a következő állításokkal? Átlagok: (7 fokú egyetértő skála 1=Nagyon nem értek egyet, $7=$ =Nagyon egyetértek)}

\section{Átlag}

Fontosnak tartom, hogy a magyar fogyasztók előnyben részesítsék a magyar termékeket.

Kedvelem a tradicionális márkákat, termékeket.

Hazafias dolgonak tartom a magyar termékek vásárlását.

Csak olyan külföldi terméket kellene megvásárolnunk, amelyeket hazánkban nem tudunk előállítani.

Mindig magyarországon előállított termékeket kellene beszereznünk ahelyett, hogy vásárlásainkkal más nemzeteket tennénk gazdaggá.

Akkor is a hazai termékeket részesítem előnyben, ha azok drágábbak, mint a külföldiek.

A külföldi termékek vásárlása árt a magyar gazdaságnak, és munkanélküliséghez vezet.

A hazai élelmiszerek kevésbé ártalmasak a fogyasztók egészségére, mint a külföldről importáltak.

Nem helyes külföldi élelmiszert vásárolni, mert ez a magyar emberek munkahelyeinek megszünéséhez vezet.

Véleményem szerint a hazai élelmiszerek jobb minőségüek, mint a külföldiek.

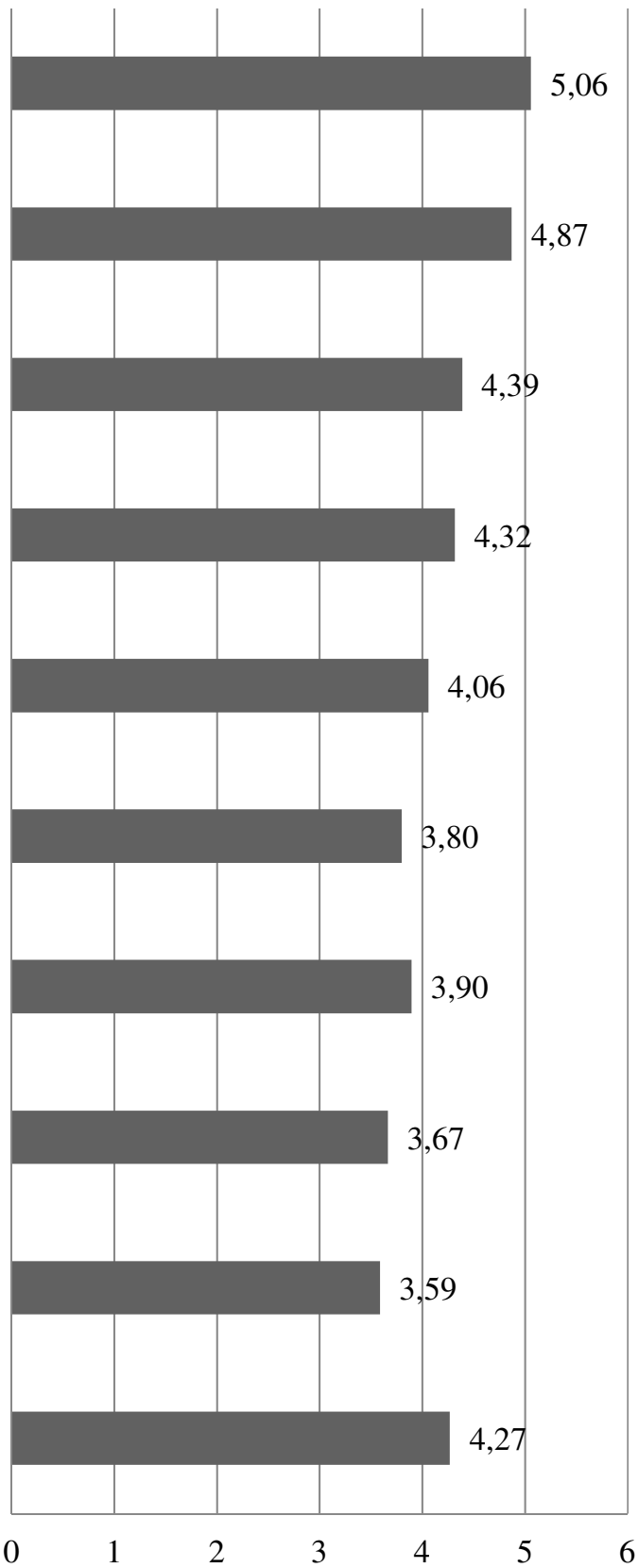

Forrás: saját szerkesztés, $2017(\mathrm{~N}=551)$ 


\section{2. ábra: Mennyire ért egyet a következő állításokkal? (TOP2=egyetértek, nagyon egyetértek, a megkérdezettek százalékában)}

\section{Egyetértés TOP2 (\%)}

Fontosnak tartom, hogy a magyar fogyasztók előnyben részesítsék a magyar termékeket.

Kedvelem a tradicionális márkákat, termékeket.

Hazafias dolgonak tartom a magyar termékek vásárlását.

Csak olyan külföldi terméket kellene megvásárolnunk, amelyeket hazánkban nem tudunk előállítani.

Mindig magyarországon előállított termékeket

kellene beszereznünk ahelyett, hogy vásárlásainkkal más nemzeteket tennénk gazdaggá.

Akkor is a hazai termékeket részesítem előnyben, ha azok drágábbak, mint a külföldiek.

A külföldi termékek vásárlása árt a magyar gazdaságnak, és munkanélküliséghez vezet.

A hazai élelmiszerek kevésbé ártalmasak a fogyasztók egészségére, mint a külföldről importáltak.

Nem helyes külföldi élelmiszert vásárolni, mert ez a magyar emberek munkahelyeinek megszünéséhez vezet.

Véleményem szerint a hazai élelmiszerek jobb minőségüek, mint a külföldiek.

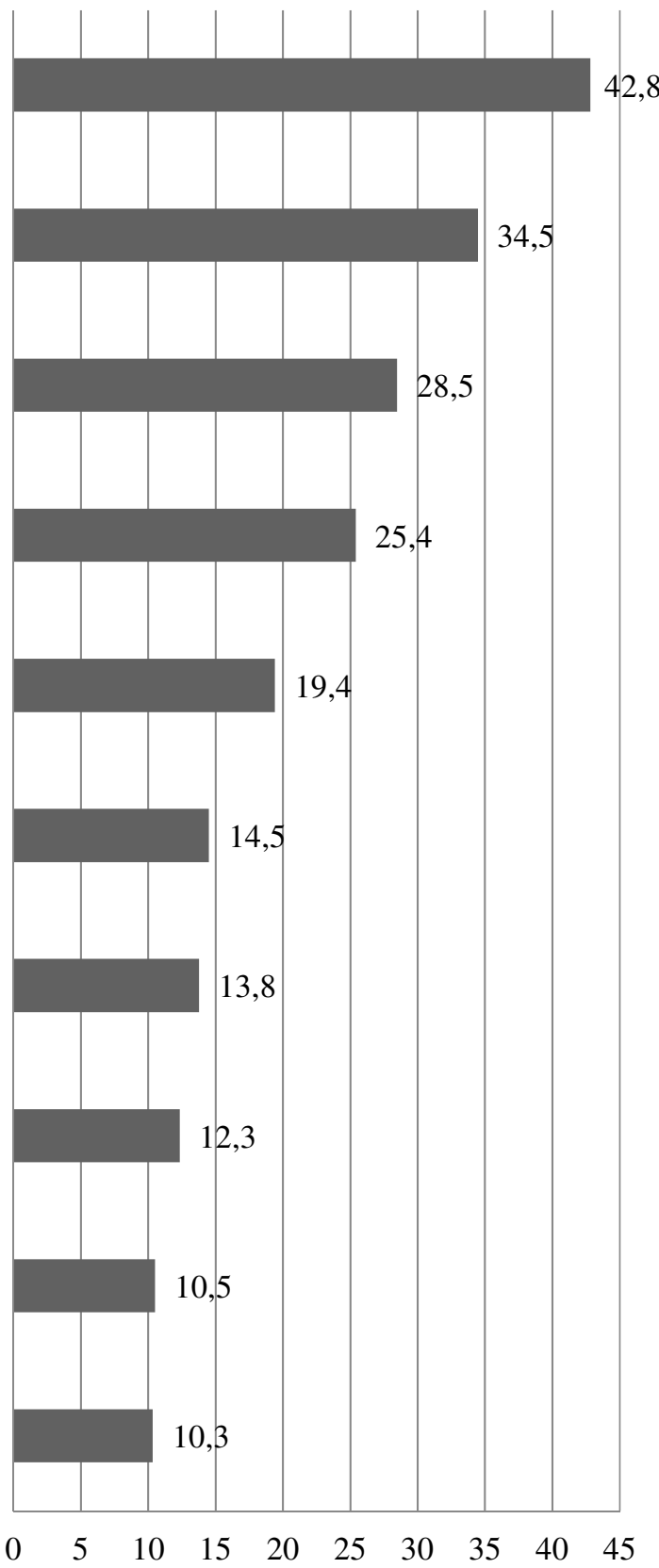

Forrás: saját szerkesztés, 2017 (N=551)

A megkérdezett fogyasztók 42,8\%-a egyetértett, vagy nagyon egyetértett a magyar élelmiszerek előnyben részesítésével. A válaszadók leginkább a tradicionális 
termékek vásárlását, valamint a magyar termékek vásárlásának hazafias voltát tartották fontosnak.

\section{Következtetések, összegzés, záró megjegyzések, záró gondolatok}

Kutatásunkban a felsőfokú végzettséggel rendelkező válaszadók felülreprezentáltak voltak. Az élelmiszer-vásárlási döntésben fontos szerepet játszó címkehasználatra irányuló kérdéseink alapján a válaszadók $48 \%$-a figyeli a termék származási helyét, $22 \%$ mindig figyeli, 26\% pedig mielőtt elöször vásárolja a terméket. A termék árának elolvasása esetében ugyanez az arány $87 \%$ volt, ami a hazai fogyasztók árérzékenységét mutatja.

A termék származási helyével kapcsolatos fogyasztói attitüd alaposabb megismeréséhez alkalmazott nyitott kérdések szerint a legfőbb okozója a termék származási helyének ignorálásának az ár volt, ezt 53 fö választotta okként. 49 fó válaszolta indok nélkül csak azt, hogy nem figyeli a származási helyet. A termék származási helyét a vásárlásuk során fontosnak tartók ezt elsősorban a minőséggel, illetve különböző termékcsoportok származási helyének jelentőségével indokolták. A válaszadók a származási hely szempontjából leginkább a friss termékeket tartották fontosnak. Sorrendben elöször a tejtermékek, majd a zöldségek, gyümölcsök, végül pedig a húsfélék megvásárlása esetében tájékozódnak a termékek származási helyéről. A megkérdezettek mindössze $8 \%$-a válaszolta azt, hogy soha nem részesíti előnyben a hazai élelmiszereket a külföldi termékekkel szemben. A válaszadók 57,6\%-a mindig, vagy gyakran preferálja a magyar termékek vásárlását. Azok a válaszadók, akik a hazai termékeket előnyben részesítik, döntésüket a magyar termékek eredetével, és a hazai gazdaság támogatásával indokolták. A válaszadók között sajnos a tanúsítványok, illetve a tanúsító védjegyek figyelembe vétele alacsony mértékü, 39,6\%-uk sohasem veszi figyelembe a védjegyeket, amikor élelmiszereket vásárol. A megkérdezettek többsége nem tudta értelmezni a tanúsító védjegy fogalmát. Legtöbben föként külföldi, és néhány magyar élelmiszer márkákat említettek. A tényleges tanúsítói védjegyek sorában első helyen a Magyar Termék, a második helyen a Hazai Termék védjegy szerepelt. Az ezen védjegyekkel ellátott termékeket válaszadóink a többi terméknél jobb minőségűnek, megbízhatóbb eredetünek gondolják. Az etnocentrikus fogyasztói magatartás megismerésére vonatkozó kérdéseink alapján az általunk megkérdezett fogyasztók majdnem fele egyetértett, vagy nagyon egyetértett a magyar élelmiszerek előnyben részesítésével. A válaszadók leginkább a tradicionális termékek vásárlását, valamint a magyar termékek vásárlásának hazafias voltát tartották fontosnak. Kutatásunk nem reprezentatív, de az eredmények jól használhatók. Válaszadóinkra jellemző volt a fogyasztói etnocentrizmus, azonban a tanúsító védjegyek ismerete, és figyelembe vétele alacsony mértékü.

A hatalmas termék kínálat és a kiéleződő piaci verseny közepette a vállalkozások számára versenyképességük növelése érdekében fontos lenne egy jól végiggondolt védjegy stratégia megválasztásával az élelmiszeripari tanúsító védjegyek alkalmazása. Azonban helyzetüket nehezíti a fogyasztók még mindig nem megfelelő 
szintü tájékozottsága, melynek javítása csak a piaci szereplők, vállalkozások, védjegy tanúsítók, szakmai közösségek együttes munkájával érhető el.

\section{Irodalomjegyzék}

1997. évi XI. törvény II. Fejezet 12. § (1), 101.§ (1) bek., a védjegyek és a földrajzi árujelzők oltalmáról (n.d.): https://net.jogtar.hu/jogszabaly?docid=99700011.TV Letöltve: 2018.05.02. 32-47.

A vidékfejlesztési miniszter 74/2012. (VII. 25.) VM rendelete egyes önkéntes megkülönböztető megjelölések élelmiszereken történő használatáról

Aboluian L., Chanley P. (2007): Legal update. The Trade Marks (Relative Grounds) Order 2007 and its impact on trade mark owners and applicants. Journal of Brand Management, 2007/15. p. 146149.

Atkin D. (2004): The Culting of Brands: When Consumers Become True Believers, Portfolio New York p. 8-16.

Babin B.J., Darden W.R., Griffin M. (1994): Work and/or fun: Measuring hedonic and utilitarian shopping value. Journal of Consumer Research. 20 (March) p. 644- 656.

Bauer A., Berács J. (2006): Marketing. Budapest: Aula Kiadó.

Betancourt R.R., Gautschi D. (1990): Demand complementarities, household production, and retail assortments. Marketing Science, 9 (2), p. 146-161.

Bettman J.R. (1979): An Information Processing Theory Of Consumer Choice, Reading, MA: Addison-Wesley.

Caswell J.A., Modjuszka E.M. (1996): Using Information Labeling to Influence the Market for Quality in Food Products. American Journal of Agricultural Economics, 78 (5) p. 1248-1253.

Caswell J.A. (2006): Quality assurance, information tracking, and consumer labeling. Marine Pollution Bulletin; 53 (10/12) p. 650-656.

Chernev A. (2003): When More Is Less and Less Is More: The Role of Ideal Point Availability and Assortment in Consumer Choice. The Journal of Consumer Research, 30 (2) p. 170-183.

Cleays C., Swinnen A., Abbeele P.V. (1995): Consumer 'Means-end Chain for "Think" and Feel" Products. International Journal of Research in Marketing, 12 (3) p. 193-208.

Copeland M.T (1923) Relation of Consumers' Buying Habits to Marketing Methods. Harvard Business Review, 1 (April) p. 282-289.

Drichoutis A.C., Lazaridis P., Nayga R.M., Jr. (2005): Nutrition knowledge and consumer use of nutritional food labels. European Review of Agricultural Economics; 32 (1) p. 93-118.

George A. (2006): Brand rules: When branding lore meets trade mark low. Brand Management 13/3 2006 February. p. 215-232.

Guo C. (2001): A Review on Consumer External Search: Amount and Determinants. Journal of Business and Psychology; 15 (3) p. 505-519

Guthrie J.F., Fox J.J., Cleveland L.E., Welsh S. (1995): Who uses nutritional labeling, and what effects does label use have on diet quality? Journal of Nutrition Education; 27 (4) p. 163-172.

http://pmsz.org/hu/kutatasok/fogyaszt\%C3\%B3i-bizalom-\%C3\%A9s$\% \mathrm{C} 3 \%$ A9lelmiszerbiztons\%C3\%A1g

http://www.gfk.com/imperia/md/content/gfk_hungaria/pdf/press_h/press_20090507\%20_h.pdf

Huddleston, P., Good L.K., Stoel L. (2001): Consumer Ethnocentrism, Product Necessity and Polish Consumer's Perception of Quality. International Journal of Retail and Distribution Management, Vol. 29/5, p. 236-246.

IKON Research Group (2000): Evidence of Home Country Bias in Evaluation of Products: A 15Country Study, Proceedings, 29th EMAC Conference, Rotterdam

Jacoby J. (1977): Information Load and Decision Quality: Some Contested Issues. Journal of Marketing Research, 14 (4) p. 569-573

Jiménez-Guerrero J. F., Gázquez-Abad J. C., Linares-Agüera E. C. (2014): Using stan- dard CETSCALE and other adapted versions of the scale for measuring consumers' ethnocentric tendencies: An analysis of dimensionality. BRQ Business Research Quarterly, 17 (3) p. 174-190. 
Katona G., Mueller E. (1954): A study of purchase decisions. In L. H. Clark (Ed.), Consumer behavior (Vol. 1, p. 30-87). New York: New York University Press.

Klopp P., McDonald M. (1981): Nutrition labels: an exploratory study of consumer reasons for nonuse. Journal of Consumer Affairs; 15 (2) p. 301-316.

Lehota J., Fürediné Kovács A. (2007): A madárinfluenza piaci hatásainak vizsgálata húsboltok vezetőivel készített interjúk alapján, AVA 3 Konferencia, Debrecen, 2007. március 20-21.

Lehota J. (2001): Élelmiszergazdasági marketing. Budapest: Müszaki Könyvkiadó

Lontai E., Faludi G., Gyertyánfy P., Vékás G. (2012): Szerzői jog és iparjogvédelem. Eötvös József Könyvkiadó, Budapest, p. 287.

Malhotra N. K. (1982): Information Load and Consumer Decision Making. The Journal of Consumer Research, 8 (4) p. 419-430.

Malota E.: Magyar termék - hazai fogyasztó. Fogyasztóvédelmi Szemle 2011. évi 2. szám 13-p. 20.

Miskolczi B.r P. (2011): Termékek „magyarként” való reklámozásának jogi kérdései. Versenytükör 2011. évi 2. szám p. 24-34.

Moorman C. (1990): The effects of stimulus and consumer characteristics on the utilisation of nutrition information. Journal of Consumer Research, 17 (4) p. 362-374.

Moorman C. (1996): A quasi experiment to assess the consumer and informational determinants of nutrition information processing activities: the case of the NLEA. Journal of Public Policy and Marketing, 15 (1) p. 28-44.

Nayga R.M. Jr (1997): Impact of sociodemographic factors on perceived importance of nutrition in food shopping. Journal of Consumer Affairs; 31 (1) p. 1-9.

Newman J. W. (1977): Consumer external search: Amount and determinants. In A. G. Woodside, J. N. Sheth, \& P. D. Bennett (Eds.), Consumer and industrial

Papadopoulos N. G., Heslop L. A., Bennett D. (1993): National Image Correlates of Products Stereotypes: A Study of Attitudes Twards East European Countries. European Advances in Consumer Research, vol. 1. p. 206-213.

Papadopoulos N. G., Heslop L. A., J. Beracs (1990): National Stereotypes and Product Evaluation in a Socialist Country. International Marketing Review, 7 (1).

Shimp T. A., Sharma S. (1987): Consumer Ethnocentrism: Construction and Validation of the CETSCALE. Journal of Marketing Research, 24 (3) p. 280-289.

Sumner W. G. (1906): Folkways: A Study of the Sociological Importance of Usages, Manners, Customs. Moves and Moral. New York, Dover Publications Inc., p. 728.

Szakály Z., Pallóné Kisérdi I., Nábrádi A. (2010): Marketing a hagyományos és tájjellegü élelmiszerek piacán, Kaposvári Egyetem, Kaposvár, p. 144-145.

Totth G., Hlédik E., Zarándné Vámosi K. (2015): A védjegyek szerepe a vásárlási döntésekben. in Dr. Bíró-Szigeti Szilvia, Dr. Petruska Ildikó, Dr. Szalkai Zsuzsanna, Kovács István, Magyar Mária: Marketing hálózaton innen és túl. Az Egyesület a Marketing Oktatásért és Kutatásért XXI. országos konferenciájának tanulmánykötete. Budapesti Müszaki és Gazdaságtudományi Egyetem: Budapest. ISBN: 9789633131 p. 137.

Wansink B. (2005): Marketing nutrition: soy, functional foods, biotechnology, and obesity. University of Illinois Press, Urbana ang Chicago 